\title{
COMPREENSÃO DE CIÊNCIA POR PROFESSORES EM FORMAÇÃO INICIAL
}

\section{SCIENCE UNDERSTANDING IN PRE-SERVICE TEACHERS}

\author{
Wagner Rodrigues Silva' \\ Renato Goveia Martins ${ }^{2}$ \\ Aylizara Pinheiro dos Reis ${ }^{3}$ \\ Bruno Reis Santana ${ }^{4}$ \\ Raimunda Araújo da Silveira ${ }^{5}$ \\ Eloiza Marinho dos Santos ${ }^{6}$ \\ Michele Silva Costa Sousa ${ }^{7}$ \\ Fernando Cardoso dos Santos ${ }^{8}$
}

Resumo: Investigamos como alguns professores em formaçāo inicial compreendem ciência e seus desdobramentos para a sociedade. Esta investigaçăo se caracteriza como um estudo bibliográfico e uma pesquisa de opiniâo. Os principais referenciais teóricos utilizados estăo situados nos estudos do letramento e da educaçăo científica. Os participantes demonstraram compreensóes simplificadas de ciência, pois reconheceram e enfatizaram as práticas de pesquisa características da grande área das ciências naturais, tendendo a menosprezar as que săo características das humanidades.

Palavras-chave: Formaçăo do professor. Letramento científico. Universidade.

1 Doutor em Linguística Aplicada - Docente da Universidade Federal do Tocantins (UFT) e Bolsista Produtividade do CNPq. wagnerodriguesilva@gmail.com

2 Mestrando em Letras: Ensino de Língua e Literatura, na Universidade Federal do Tocantins (UFT), e Bolsista de Mestrado CAPES. regoveia7@gmail.com

3 Doutoranda em Letras: Ensino de Língua e Literatura, na Universidade Federal do Tocantins (UFT); servidora da SEMED/Araguaína e da SEDUC/TO. ayli1986@hotmail.com

4 Mestrando em Letras, na Universidade Federal do Tocantins (UFT) e servidor efetivo na mesma instituiçâo.professorbrunoreis@gmail.com

5 Doutoranda em Letras: Ensino de Língua e Literatura, na Universidade Federal do Tocantins (UFT) e professora da Rede Estadual de Ensino do Tocantins. haydisil@hotmail.com

6 Doutoranda em Letras: Ensino de Língua e Literatura, na Universidade Federal do Tocantins (UFT) e docente da Universidade Federal do Maranhăo (UFMA). eloped.sup@gmail.com

7 Mestranda em Letras, na Universidade Federal do Tocantins (UFT) e servidora efetiva na mesma instituiçăo. michele2_sc@yahoo.com.br

8 Mestrando em Letras, na Universidade Federal do Tocantins (UFT) e docente efetivo na mesma instituiçâo. fernandosantos@uft.edu.br 
Abstract: We investigate how some pre-service teachers understand science and its impact on society. This research consists of a bibliographic study and an opinion poll. The main theoretical references used are located in literacy and scientific educational studies. The participants demonstrated a simplified understanding of science in recognizing and emphasizing the research practices which are characteristic of the large area of the natural sciences, tending to disregard the ones which are characteristics of the humanities.

Keywords: Scientific literacy. Teacher education. University.

\author{
A liçăo maior que tiro disso é que temos de reforçar nas escolas \\ o estudo da ciência. O método científico năo precisa ser aprendido \\ só por quem faz medicina9 (Paulo Hoff, 2017).
}

\title{
INTRODUÇÃO
}

A epígrafe deste artigo reproduz o ponto de vista do médico e pesquisador Dr. Paulo Hoff, após ter sido alvo de diversas críticas, especialmente por ter suspendido um estudo clínico com a fosfoetanolamina. Para o criador do composto, o químico brasileiro Dr. Gilberto Chierice, o produto teria resultados promissores em diversos tipos de câncer. Alguns magistrados autorizaram o uso do composto para pacientes oncológicos, mas o benefício alcançado em alguns pacientes era insignificante considerando o quantitativo dos voluntários que năo apresentaram melhoras com o tratamento oferecido. Segundo o julgamento do médico, a manutençăo desse mesmo estudo, diante do resultado produzido, implicaria num problema ético. 0 pesquisador expressou surpresa "com a reaçâo nâo só dos magistrados, que admitiram o uso da substância, mas de outras pessoas também com alta escolaridade, líderes de opiniăo, políticos, defendendo o composto".

Segundo Paulo Hoff, a polêmica seria evitada caso as escolas enfatizassem o trabalho pedagógico em torno dos métodos científicos. Por outro lado, defendemos que apenas o metaconhecimento sobre pesquisa pode năo garantir os saberes necessários ao exercício da cidadania diante de fatos do domínio científico. Esse conhecimento náo é suficiente, por exemplo, para o leitor se posicionar frente à entrevista publicada. É preciso discernir os interesses subjacentes às vozes identificáveis na referida publicaçăo, as quais se encontram em disputa no caso da fosfoetanolamina. Nesse sentido, é preciso considerar que o domínio científico também é atravessado minimamente por influências econômicas e políticas.

9 Revista Veja, entrevista com Paulo Hoff, nas páginas amarelas. O médico que vale ouro. 2550 ed. Ano 50, n. 40, p. 15-17, 4 de outubro de 2017. 
Considerando a relevância da escrita no funcionamento das atividades organizadoras do domínio científico, bem como as interaçōes influenciadas por saberes científicos, envolvendo especialistas ou cidadáos comuns, apreendemos essas práticas como objeto de pesquisa na Linguística Aplicada (LA), situado mais precisamente no campo de estudos do letramento científico. Concebemos a LA como um campo de investigaçăo indisciplinar de problemas sociais relativos a usos da linguagem em diferentes domínios da vida (cf. PENNYCOOK, 2001).

Neste artigo, investigamos como alguns professores em formaçăo inicial, matriculados em licenciaturas de diferentes áreas do conhecimento, compreendem ciência e seus desdobramentos para a sociedade. Defendemos a hipótese de que as compreensôes compartilhadas refletem a história das construçōes paradigmáticas em torno da ciência, bem como o trabalho de educaçăo científica desenvolvido na licenciatura em que os acadêmicos estâo matriculados.

Esta pesquisa se justifica pela relevância da promoçăo de investigaçóes e reflexôes sobre a educaçấo científica na universidade. $O$ interesse pelos acadêmicos das licenciaturas se justifica pela demanda existente do trabalho com pesquisa junto aos alunos da escola básica, futuro local de trabalho dos participantes desta investigaçăo. As demandas existentes estăo registradas na literatura especializada e em diretrizes curriculares (cf. BRASIL, 2017; DEMO, 2010; SILVA, GUIMARÂES, MEDEIROS, 2018; SILVA, TAVARES, VELEZ, 2017) ${ }^{10}$.

Este artigo está organizado em três principais seçóes, além desta introduçăo, das consideraçôes finais e das referências. Na primeira, apresentamos uma breve revisâo histórica de diferentes compreensōes de ciência, além da concepçáo de letramento científico assumida nesta pesquisa. Na segunda, descrevemos os procedimentos metodológicos assumidos na investigaçâo realizada. Na terceira, exemplificamos algumas análises de depoimentos com percepçôes de ciência compartilhadas pelos participantes desta pesquisa, além de apresentarmos alguns encaminhamentos para a formaçâo inicial de professores nas licenciaturas.

\section{SÍNTESE DA HISTÓRIA DA CIÊNCIA}

O que é ciência? Essa é uma pergunta de difícil resposta, conforme revelaram alguns participantes desta pesquisa. Certamente, uma grande parcela da sociedade que fosse questionada a esse respeito apresentaria dificuldades em conceituá-la, especialmente as pessoas mais distantes do contexto universitário. Provavelmente, isso também ocorre devido à própria trajetória da ciência com características e compreensóes distintas ao longo da história. Essa é a perspectiva historicista defendida por Thomas Kuhn (2009[1962]), em contraposiçăo à perspectiva formalista, que vê a ciência como atividade racional.

A ciência foi/está se construindo no decorrer da história, por isso, năo podemos afirmar que exista uma única concepçăo, que determinado conceito esteja correto

10 Esta pesquisa também resultou na produçâo do seguinte documentário: “Letras com Ciências". Direçâo: Wagner Rodrigues Silva, Ediçáo: Bruno Reis Santana, Victor Chiang Braga Barroso Mendes. Palmas, TO: 2017. Disponível em: 〈https://www.youtube.com/watch?v=Vb2DhVUZVco〉. Acesso em: 05 fev. 2018. 
e outros errados, pois cada período teve suas marcas, suas verdades e, até mesmo, vozes legitimadas e vozes silenciadas. Assim, o que podemos afirmar é que existem compreensôes a respeito da ciência que se encaixam em determinados momentos e contextos (cf. CHASSOT, 2004).

Na Figura 1, apresentamos uma síntese do pensamento científico ocidental em períodos distintos a partir de Chassot (2004). Com essa sistematizaçâo, o leitor poderá compreender os principais momentos transcorridos pelos cientistas em diferentes campos do conhecimento até chegar aos nossos dias.

Figura 1: Síntese do pensamento científico na história ocidental

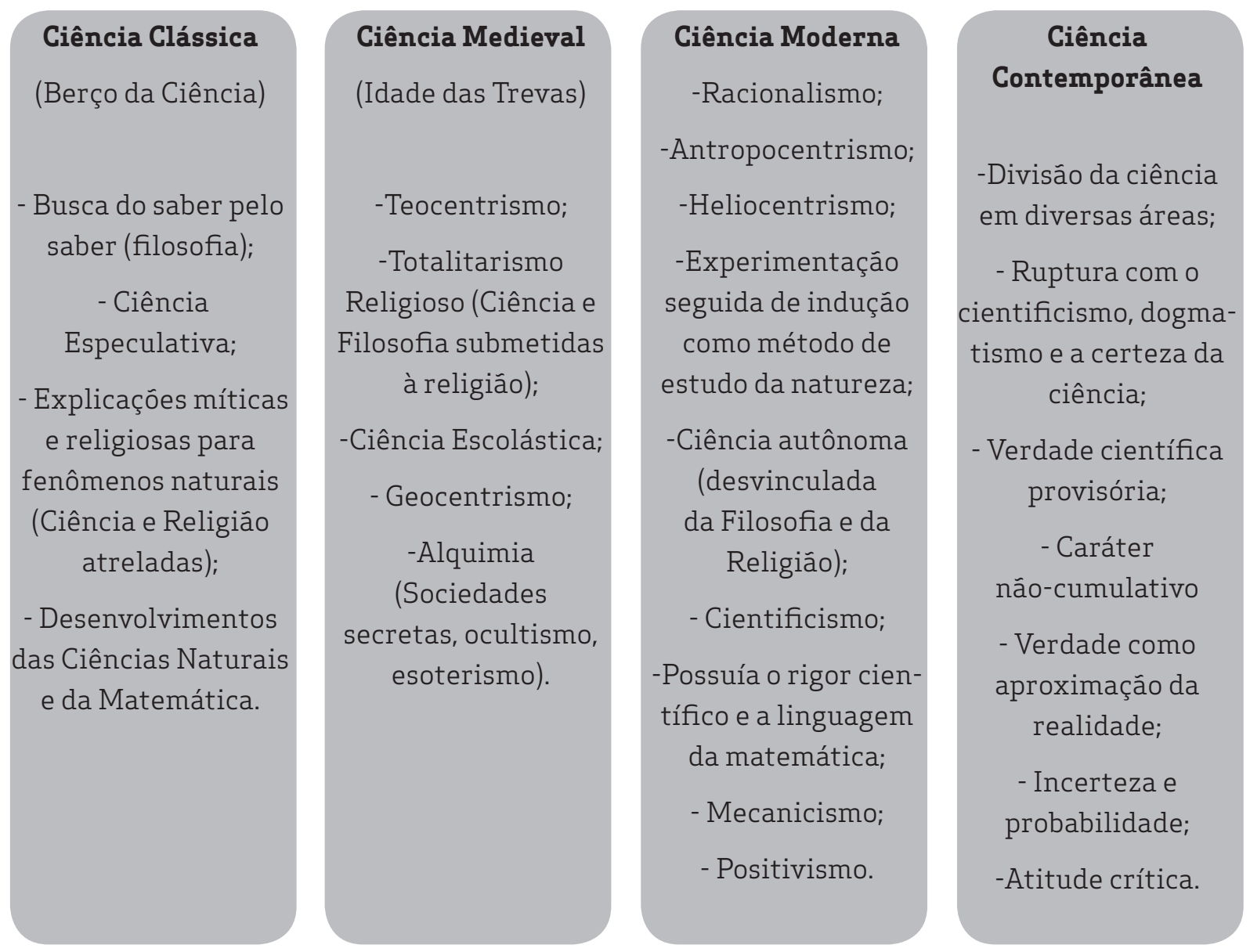

Fonte: adaptado de Chassot (2004)

A partir da Figura 1, é perceptível a transitoriedade das características que marcaram a prática científica. O surgimento da ciência foi assinalado pela curiosidade e pela pressuposiçâo. Na Idade Média, a ciência esteve voltada para o misticismo, esoterismo. Já no período marcado pela Revoluçâao Científica Moderna, houve uma nova concepçăo, caracterizada pela objetividade, uso de métodos científicos identificados como modernos por serem baseados em comprovaçôes com experimentaçôes e utilizando-se da linguagem científico-matemática. Esse período assinalou o grande apogeu 
da ciência e é responsável pelo paradigma dominante de pesquisa ainda bastante influente (cf. SANTOS, B., 2008). Mais tarde, essa mesma ciência, marcada por certezas, entra em crise e, entâo, emerge um novo modelo reconhecido pela incerteza, denominado de ciência pós-moderna e responsável pelo paradigma emergente de pesquisa (cf. SANTOS, B, 2008).

A partir da obra "A estrutura das revoluçōes científicas", Thomas Kuhn (2009[1962]) apresenta uma forma diferenciada de ver a ciência, pois passa a considerar próprios da ciência os aspectos históricos e sociológicos. Embora esse novo modelo caracterize o período que estamos vivendo, ainda nos encontramos imersos em uma cultura de valorizaçáo da ciência positivista, que prega a ciência como "pronta, acabada, completamente despojada como uma nova e dogmática religiăo, com o 'deus saber' imperando no novo milênio" (CHASSOT, 2004, p. 256). Nesse sentido, Chassot (2014, p. 207) chama a atençăo para o fato de que "mesmo vivendo a Ciência essas incertezas em nossos dias, há ainda um grande elitismo entre os cientistas". Nas palavras de Kuhn (2009[1962], p. 223):

A comunidade mais global é composta por todos os cientistas ligados às ciências da natureza. Em um nível imediatamente inferior, os principais grupos científicos profissionais sâo comunidades: físicos, químicos, astrônomos, zoólogos e outros similares. Para esses agrupamentos maiores, o pertencente a uma comunidade é rapidamente estabelecido, exceto nos casos limites. Possuir a mais alta titulaçăo, participar de sociedades profissionais, ler periódicos especializados săo geralmente condiçôes mais que suficientes.

Chassot (2017, p. 216) afirma que foi a partir das ideias de Kuhn que "deixamos de ver o saber científico como um processo linear de construçăo e descoberta de verdades objetivas e de construçâo progressiva da sociedade em torno da verdade". A Figura 2 corresponde a um esforço de representaçăo da visăo de Kuhn (2009[1962]) a respeito do desenvolvimento da ciência ao longo do tempo. Representa o círculo completo das transformaçôes paradigmáticas necessárias para o estabelecimento da ciência normal, o que nâo ignora as interrupçóes ou mudanças passíveis de instauraçăo no percurso indicado pelas setas.

Para o autor, a ciência passa por um processo de transformaçăo que parte da aceitaçăo à ruptura de um paradigma, quando outro se origina. Segundo Kuhn (2009[1962], p. 220), o paradigma, por um lado, "indica toda a constelaçáo de crenças, valores, técnicas etc., partilhadas pelos membros de uma comunidade"; por outro lado, "denota um tipo de elemento dessa constelaçâo: as soluçôes concretas de quebra-cabeças que, empregadas como modelos ou exemplos, podem substituir regras explícitas como base para a soluçâo dos restantes quebra-cabeças da ciência normal". Podemos exemplificar esse termo nos utilizando das teorias que vimos surgindo ao longo da história e, em seguida, sendo substituídas por outras. Se citarmos a própria virada do geocentrismo para o heliocentrismo, teremos um bom exemplo do que seja uma transformação paradigmática.

A análise da Figura 2 permite observar ainda a existência de um momento que antecede o que o autor chama de ciência normal. Esse momento é caracterizado pela coexistência de paradigmas que a comunidade científica ainda năo aprovou ou năo chegou a um consenso para que sejam reconhecidos como tal. Esse momento é chamado de pré-paradigmático. De forma mais precisa, instaura-se entre as etapas três, momento 
em que o modelo entra em crise, e um, quando se instaura a ciência normal, no sentido indicado pelas setas da figura ${ }^{11}$.

Figura 2: Círculo de Kuhn

1. Ciência

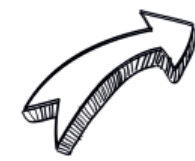

Normal

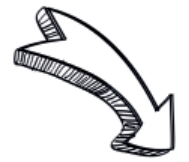

\section{Mudança}

de Paradigma

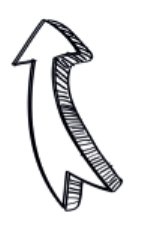

4. Modelo
Círculo de Kuhn

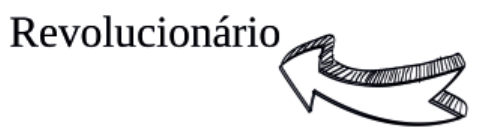

2. Modelo

Resultante

Fonte: adaptado de Kuhn (2009[1962])

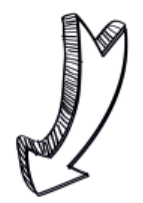

3. Crise

do Modelo

O período da ciência normal é caracterizado pelo desenvolvimento de atividades baseadas em um paradigma. Nessa fase, a comunidade científica trabalha para sustentar a validaçâo do paradigma. Porém, nem sempre o dominante é reconhecido por muito tempo, pois, em alguns casos, năo consegue resolver todos os problemas apresentados. É nesse momento que o paradigma dominante entra em crise e, com o passar do tempo, pode ser abandonado. Isso ocorre devido à percepçáo de "anomalias ou violaçóes de expectativa" na ciência normal (KUHN, 2009[1962], p. 14). Depois da crise do paradigma dominante, surge a ciência revolucionária ou revoluçâo científica, momentos curtos de transformaçăo radical do modelo vigente que origina um novo paradigma. Assim, percebemos que as etapas de construçâo de paradigmas sâo cíclicas, vâo da aceitaçâo à ruptura e se repetem continuamente, por um período muito longo da história.

É com base nessa concepçâo de ciência como processo metódico que a academia mantém, "ainda, hoje, um ranço conservador e até inquisitorial diante do conhecimento popular, que lembra tempos medievais em que nasceu a universidade. Só tem valor aquilo que ela valida" (CHASSOT, 2007, p.211). O posicionamento frequente da universidade alimenta ainda, uma visăo limitada de ciência, ignorando ou desvalorizando os saberes científicos produzidos nas ciências humanas e sociais, além dos saberes populares produzidos por năo especialistas. Em sua tese das linhas abissais estruturadoras

11 Lembramos aqui da seguinte definiçâo de paradigma apresentada por Kuhn (2009[1962], p. 221): “um paradigma é aquilo que os membros de uma comunidade partilham e, inversamente, uma comunidade científica consiste em homens que partilham um paradigma" (itálico do original). 
do conhecimento, Boaventura Santos (2010, p. 55) complexifica a compreensăo da denominada ciência moderna ${ }^{12}$ :

O que é característico do nosso tempo é o facto de a ciência moderna pertencer simultaneamente ao campo das ideias e ao campo das crenças. A crença na ciência excede em muito o que as ideias científicas nos permitem realizar. Assim, a relativa perda de confiança epistemológica na ciência, que percorreu toda a segunda metade do século XX, ocorreu de par com a crescente crença popular na ciência. A relaçáo entre crenças e ideias deixa de ser uma relaçáo entre duas entidades distintas para passar a ser uma relaçăo entre duas formas de experienciar socialmente a ciência. Esta dualidade faz com que o reconhecimento da diversidade cultural do mundo nâo signifique necessariamente o reconhecimento da diversidade epistemológica do mundo.

De acordo com Chassot (2014), é perceptível a necessidade de refletir sobre o ensino ofertado nas universidades, de modo que os acadêmicos se tornem pessoas educadas cientificamente, a fim de buscar a "valorizaçăo do conhecimento dito náo científico" (p. 98; grifo do original), "despir-se de posturas cientificistas" (p. 67) e "colocar o qualificativo 'transitório' naquilo que ensinamos, pois há assuntos que aprendemos (e ensinamos) como se fossem dogmas" (p.179).

Nesta pesquisa, apropriamo-nos de algumas orientaçôes teóricas subjacentes à abordagem do letramento científico, assumindo uma perspectiva alinhada aos trabalhos mais clássicos dos estudos do letramento, desenvolvidos nas ciências sociais, predominantemente na LA (BARTON; PAPEN, 2010; KLEIMAN, 1995; MARINHO; CARVALHO, 2010; SILVA, 2016; SOARES, 2003). A terminologia letramento científico é corriqueira no campo do ensino de ciências, onde há uma oscilaçăo nem sempre esclarecedora entre os usos da referida nomenclatura e da alfabetizaçâo científica (cf. AKDUR, 2009; SANTOS, W., 2007; CHASSOT, 2014; 2013). Sobre o uso da terminologia scientific literacy, que, em língua portuguesa, pode ser traduzida como letramento científico ou alfabetizaçâo científica, Cunha (2017, p. 176) esclarece que:

[...] se iniciou, por um lado, com a preocupaçăo em conquistar o apoio público às pesquisas científicas e tecnológicas - majoritariamente financiadas com recursos públicos - e, por outro lado, com a preocupaçáo das famílias com um ensino que capacitasse seus filhos para competir em um mercado de trabalho cada vez mais modificado pelos avanços científicos e tecnológicos, as últimas décadas têm direcionado tal debate para a necessidade do público e de seus representantes nas tomadas de decisóes políticas terem uma base suficientemente sólida para a avaliaçăo dos benefícios e dos riscos de cada avanço científico e tecnológico, das questôes éticas envolvidas, dos impactos socioambientais comparados aos impactos econômicos, entre outras questóes envolvendo ciência e tecnologia.

Defendemos a utilizaçâo das nomenclaturas letramento e alfabetizaçâo científica para identificar práticas e saberes complementares, diferenciados e necessários ao produtivo trânsito do cidadāo pelo domínio científico ou ao conhecimento do referido domínio. Concebemos letramento científico como a diversidade de práticas

12 Para Boaventura Santos (2010, p. 31), "o pensamento moderno ocidental é um pensamento abissal", responsável por uma divisáo espacial nem sempre física entre elementos visibilizados por serem legitimados num lado da linha, e elementos invisibilizados por serem ignorados do outro lado da linha. 
interativas em que os saberes científicos exercem alguma funcionalidade, podendo haver, na própria interaçăo, considerando a história da ciência, reconhecimento da participaçâo dos atores que compartilham conhecimentos legitimados ou menosprezo dos que compartilham saberes marginalizados. A alfabetizaçâo científica, por sua vez, está condicionada à apropriaçâo dos saberes formais referentes aos procedimentos necessários para o desenvolvimento de práticas investigativas em diferentes campos ou áreas do conhecimento. Em síntese, o letramento envolve as práticas e implicaçôes sociais em torno do domínio científico, ao passo que a alfabetizaçáo está atrelada ao metaconhecimento sobre a ciência ${ }^{13}$.

\section{PERCURSO INVESTIGATIVO CONSTRUÍDO}

Esta pesquisa pauta-se em uma abordagem qualitativa de investigaçăo, uma vez que apreendemos alguns detalhes do contexto instrucional de licenciaturas a partir da investigaçăo de depoimentos compartilhados por professores em formaçăo inicial. Trata-se de uma pesquisa na área das ciências sociais, onde a subjetividade é o foco central a ser analisado. Segundo Flick (2004, p. 22),

De modo diferente da pesquisa quantitativa, os métodos qualitativos consideram a comunicaçáo do pesquisador com o campo e seus membros como parte explícita da produçáo de conhecimento, ao invés de exclui-la ao máximo como uma variável intermediária. As subjetividades do pesquisador e daqueles que estăo sendo estudados săo parte do processo de pesquisa.

No entanto, com o intuito de facilitar a compreensâo do leitor e de garantir a visibilidade das análises realizadas, também utilizamos elementos da abordagem quantitativa. Com o uso de gráficos, demonstramos alguns resultados da análise do número de ocorrência das categorias analíticas elaboradas a partir das respostas compartilhadas pelos participantes em entrevistas espontâneas realizadas.

Em consonância com a perspectiva indisciplinar dos estudos linguísticos aplicados, esta investigaçăo está fundamentada em literaturas científicas produzidas no campo do ensino de ciências, ciências sociais, história do conhecimento e da própria LA. Nessa perspectiva, esforçamo-nos para complexificar nosso objeto de pesquisa, que sâo as representaçóes em torno de práticas científicas compartilhadas por acadêmicos de licenciaturas. Buscamos desenvolver uma conduta colaborativa entre participantes e pesquisadores, a fim de produzir reflexóes e encaminhamentos viáveis para a educaçăo científica nas licenciaturas. Nas palavras de Celani (2005, p. 103), buscamos investigar "com humildade para entender e com grandeza para mudar".

Trabalhamos com as modalidades de investigaçăo bibliográfica e de opiniâo. A pesquisa bibliográfica nos forneceu subsídios teóricos acerca da temática abordada, o que nos possibilitou analisar os dados a partir do confronto com os referenciais

13 Elaboramos tais acepçōes a partir das concepçōes originárias mais corriqueiras e compartilhadas de alfabetizaçáo e letramento, a exemplo da explicitada por Soares (2003, p. 90), mesmo correndo "o risco de uma excessiva simplificaçăo": "a inserçáo no mundo da escrita se dá por meio da aquisiçáo de uma tecnologia - a isso se chama alfabetizaçấo, e por meio do desenvolvimento de competências (habilidades, conhecimentos e atitudes) de uso efetivo dessa tecnologia em práticas sociais que envolvem a língua escrita - a isso se chama letramento" (itálico do original). 
mobilizados. Em relaçăo à pesquisa de opiniâo, utilizamos como instrumento de geraçâo de dados uma breve entrevista como roteiro prévio para orientar os diálogos presenciais entre pesquisadores e participantes. De acordo com May (2004, p.145), "as entrevistas geram compreensóes ricas das biografias, experiências, opiniōes, valores, aspiraçōes, atitudes e sentimentos das pessoas".

$\mathrm{Na}$ entrevista, utilizamos dois questionamentos para os participantes responderem: (1) Certamente, você já ouviu falar sobre pesquisa científica. O que você compreende por fazer ciência? (2) Mencione algumas situaçóes na sociedade em que os conhecimentos produzidos pela ciência podem contribuir para solucionar ou aliviar problemas sociais. Essas provocaçôes poderiam sofrer alguma alteraçáo em sua construçăo conforme a espontaneidade assumida por diferentes pesquisadores durante a entrevista. A depender da resposta compartilhada pelos participantes, especialmente nos casos em que a própria área da licenciatura cursada fora ignorada na resposta, alguns entrevistadores fizeram um questionamento adicional: (3) Saberia dizer, dentro da sua área, algum exemplo de prática ou contribuiçâo científica? Essa última pergunta também estava sujeita a sofrer alguma alteraçấo em sua construçáo.

No processo de elaboraçâo dos questionamentos, consideramos alguns propósitos pontuais para selecionar as perguntas. Com a primeira, pretendíamos apreender as noçóes de ciência compartilhadas pelos participantes. Com a segunda, pretendíamos verificar se os participantes relacionavam as funçóes ou objetivos da ciência às próprias áreas de formaçáo. Ao longo da geraçăo dos dados, percebemos que, de alguma forma, essa segunda pergunta induzia os entrevistados a pensarem apenas nas contribuiçôes, ignorando alguns prejuízos instaurados pela própria atividade científica, o que fora lembrado por alguns participantes.

As entrevistas foram realizadas com vinte e três acadêmicos matriculados entre o segundo e o nono período de onze licenciaturas representando diferentes áreas do conhecimento, em instituiçôes públicas federais e estaduais na Regiăo Nordeste e na Regiăo Norte. Durante a gravaçăo dos vídeos, todos os participantes autorizaram a identificaçăo pessoal, porém, para evitar algum tipo de exposiçăo ou constrangimento indesejado, nâo identificamos os alunos das licenciaturas pelo nome próprio, nem as instituiçōes por eles representadas, conforme elencado no Quadro 1. A escolha dos acadêmicos aconteceu aleatoriamente, pois priorizamos a participaçâo dos dois primeiros voluntários de cada licenciatura para realizar uma entrevista espontânea no momento em que os pesquisadores foram às instituiçôes de ensino superior. 
Quadro 1: Participantes da pesquisa

\begin{tabular}{|c|c|c|c|c|}
\hline \multirow{2}{*}{\multicolumn{2}{|c|}{ INSTITUIÇÃO }} & \multirow{3}{*}{$\begin{array}{l}\text { LICENCIATURA } \\
\text { Física }\end{array}$} & \multicolumn{2}{|c|}{ PARTICIPANTE } \\
\hline & & & QUANTIDADE & IDENTIFICAÇÃO \\
\hline \multirow{8}{*}{ UNI1 } & \multirow{4}{*}{ Câmpus 1} & & F1; F2 & 02 \\
\hline & & Biologia & B1; B2 & 02 \\
\hline & & Geografia & G1; G2 & 02 \\
\hline & & Química & Q & 01 \\
\hline & Câmpus 2 & Educação Física & EF1; EF2 & 02 \\
\hline & \multirow{2}{*}{ Câmpus 3} & Filosofia & FL1; FL2 & 02 \\
\hline & & Artes & $\mathrm{A} 1 ; \mathrm{A} 2$ & 02 \\
\hline & Câmpus 4 & Letras & L1; L2 & 02 \\
\hline \multirow{2}{*}{$\mathrm{IF} 1$} & \multirow{2}{*}{ Palmas } & Educação Física & EF3; EF4 & 02 \\
\hline & & Matemática & M1; M2 & 02 \\
\hline UN2 & Câmpus 1 & Pedagogia & P1; P2 & 02 \\
\hline UN3 & Câmpus 1 & História & $\mathrm{H} 1 ; \mathrm{H} 2$ & 02 \\
\hline \multicolumn{3}{|c|}{ TOTAL } & \multicolumn{2}{|c|}{23} \\
\hline
\end{tabular}

Fonte: autoria própria

Conforme o Quadro 1, os participantes sâo identificados nesta pesquisa pela combinaçâo das iniciais dos nomes das licenciaturas e dos numerais 1 ou 2 , uma vez que procuramos manter a padronizaçăo de dois participantes por licenciatura, o que nos escapou na Licenciatura em Química, com apenas um parti cipante, e na Licenciatura em Educaçâo Física, com quatro participantes.

As entrevistas foram gravadas em vídeo com uso dos aparelhos celulares dos próprios pesquisadores. Posteriormente, foram transcritas pelos próprios responsáveis por cada entrevista com o objetivo de facilitar a análise linguística do corpus produzido. Para padronizar a escrita das transcriçôes, optamos por seguir o registro padrâo da língua portuguesa, sem marcaçóes salientes da variedade linguística oral utilizada pelos participantes, uma vez que a variaçăo linguística năo é objeto de estudo na pesquisa. Nas transcriçóes, observamos ainda as seguintes convençōes sistematizadas pelos pesquisadores envolvidos: (...) pausa longa; [...] corte do texto em funçâo da seleçâo do excerto para análise; ::: alongamento da realizaçáo de alguns fonemas durante a fala.

\section{COMPREENSÕES DE CIÊNCIA POR ACADÊMICOS}

A partir da heterogeneidade das respostas dos vinte e três entrevistados, elaboramos quatro categorias analíticas complementares, reunindo as compreensôes de ciência, compartilhadas pelos professores em formaçăo inicial: (1) solucionadora de problema social; (2) produtora de conhecimento; (3) reprodutora de conhecimento; e (4) desencadeadora de estudo ou investigaçâo. O Gráfico 1 apresenta a proporçāo das compreensóes sobre ciência compartilhadas conforme as categorias analíticas elencadas. A interpretaçâo do gráfico pode ser complementada a partir da análise qualitativa adiante. 
Gráfico 1: Compreensăo de ciência

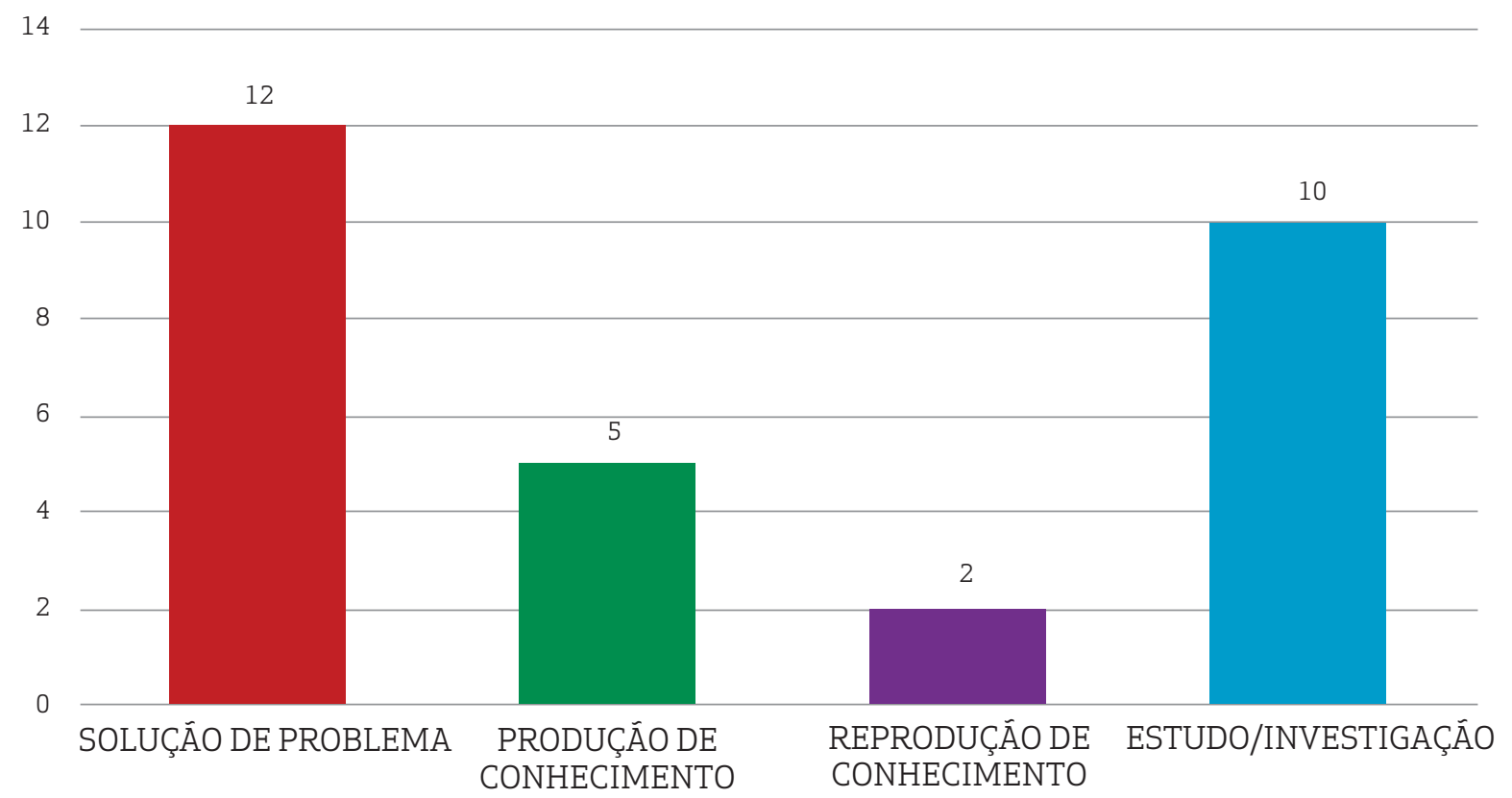

Fonte: autoria própria

As categorias analíticas se complementam e representam compreensôes viáveis da prática científica. A separaçăo das categorias foi uma opçăo realizada em funçăo da clareza da nossa explicaçâo. Os vinte e nove registros de respostas no Gráfico 1 se justificam por haver seis respostas compartilhadas que se situam em mais de uma categoria. Para ilustrar essa fluidez das compreensôes de ciência explicitadas, produzimos o Gráfico 2:

Gráfico 2: Fluidez das compreensōes de ciência compartilhadas

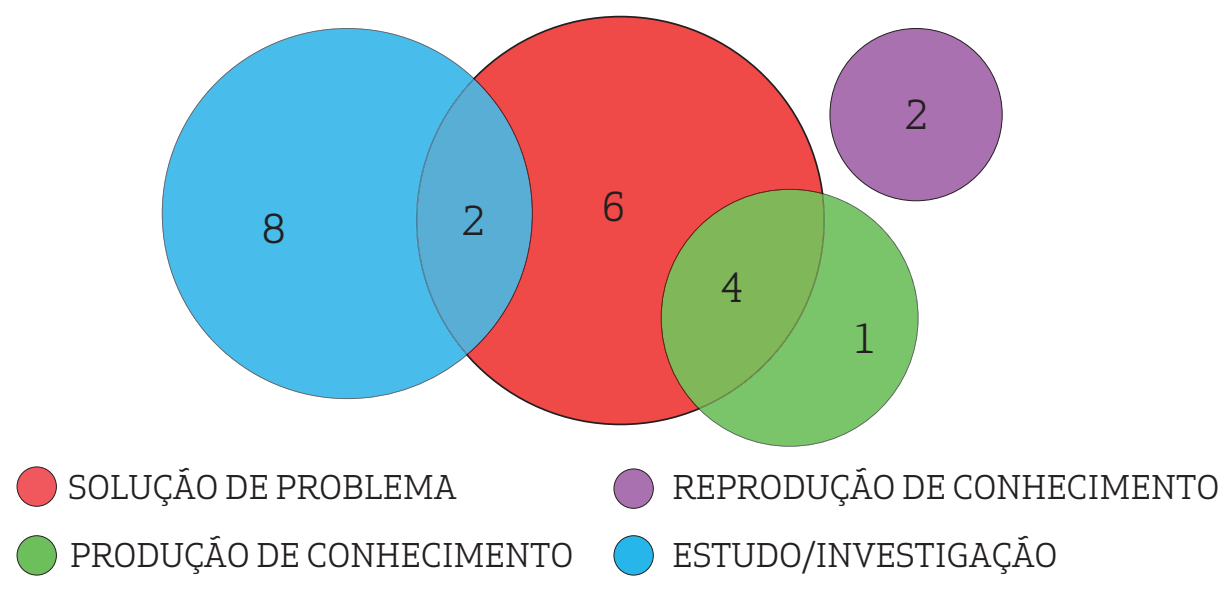

Fonte: autoria própria 
Como é possível observar no Gráfico 2, há dez respostas categorizadas como compreensăo de ciência desencadeadora de estudo ou investigaçáo. No entanto, duas dessas respostas possibilitaram categorizar ciência como solucionadora de problema social. No Exemplo 1, ilustramos um tipo de intersecçăo entre as categorizaçôes das respostas compartilhadas.

\section{Exemplo 1: Participante EF4}

Resposta para questāo 1

"É a arte assim de evoluir algo já criado ou mesmo de criar algo novo, está sempre assim em busca de desenvolver para contribuir para algo assim na sociedade".

No Exemplo 01, encontramos a intersecçăo mais evidente das categorias ciência como produtora de conhecimento e solucionadora de problema social. A primeira é perceptível quando se fala em "evoluir algo já criado", ou seja, dar continuidade ao desenvolvimento de algum produto conhecido. Na sequência, faz-se referência ao "criar algo novo", que também nos remete à funçăo de produçăo de conhecimento. A segunda categoria mencionada é sinalizada quando se afirma "desenvolver para contribuir para algo assim na sociedade".

Na categoria ciência como solucionadora de problema social, na qual está inserido o maior número das compreensóes compartilhadas, estâo inclusos dois participantes que năo explicitaram noçăo alguma de ciência diante do primeiro questionamento realizado. No entanto, em suas respostas para o segundo questionamento (Mencione algumas situaçóes na sociedade em que os conhecimentos produzidos pela ciência podem contribuir para solucionar ou aliviar problemas sociais), tais participantes formularam respostas alinhadas à concepçăo de ciência como solucionadora de problema social ("desse produto que a ciência desenvolve pra que a gente possa melhorar nossa realidade"). Certamente, isso ocorreu porque o próprio comando da entrevista solicita que sejam explicitadas soluçóes ou respostas para demandas sociais, o que talvez justifique o maior número de ocorrência dessa categoria, conforme mostrado no Gráfico 1, ainda que o direcionamento da resposta só apareça na segunda questăo.

\begin{tabular}{|c|}
\hline \\
\hline $\begin{array}{l}\text { Resposta para questăo } 1 \\
\text { "Com relaçáo à questâo científica, o que é que eu compreendo e entendo pela essa questâo da ciência dentro } \\
\text { da universidade. Eu acredito que é de fundamental importância, porque a gente é estruturado num tripé: } \\
\text { ensino, pesquisa e extensâo, e::: é desenvolver esse ensino dentro de sala de aula que é o conhecimento } \\
\text { científico, é::: também desenvolver os programas de extensăo e a própria pesquisa, săo de fundamental } \\
\text { importância pra que a gente desenvolva aqui dentro da universidade e possa levar isso para fora da } \\
\text { universidade e poder aplicar juntamente com a sociedade". }\end{array}$ \\
\hline Exemplo 3: Participante H1 \\
\hline $\begin{array}{l}\text { Resposta para questăo } 2 \\
\text { [.... "eu percebo que a sociedade precisa muito de ciência, desse produto que a ciência desenvolve pra que a } \\
\text { gente possa melhorar nossa realidade". }\end{array}$ \\
\hline
\end{tabular}

Em resposta ao primeiro questionamento, H1 comenta a relevância das atividades de ensino, pesquisa e extensâo na universidade, pontuando como elas estăo interligadas ("ensino dentro de sala de aula que é o conhecimento científico"). Ao final do excerto do Exemplo 2, observamos que $\mathrm{H} 1$ sinaliza sutilmente que as atividades de extensăo e 
pesquisa estabelecem algum diálogo entre as comunidades interna e externa à universidade ("săo de fundamental importância pra que a gente desenvolva aqui dentro da universidade e possa levar isso para fora da universidade e poder aplicar juntamente com a sociedade"). O Exemplo 3 ilustra a compreensâo de ciência como solucionadora de problema social ("a sociedade precisa muito de ciência, desse produto que a ciência desenvolve pra que a gente possa melhorar nossa realidade"), o que só ocorreu em resposta ao segundo questionamento.

No Exemplo 4, ilustramos um excerto com uma das duas ocorrências em que a ciência é compreendida como reprodutora de conhecimento.

\section{Exemplo 4: Participante FL2}

Resposta para questăo 01

Eu acho que é assim, na questăo de trabalho científico, o conhecimento científico eu percebo que é só uma cópia do que já fizeram. Porque eu tenho que comprovar aquilo que eu estou falando. Entăo eu tenho que pegar aquilo que já existe e aí colocar minhas ideias, mas sendo assim, tendo base aquilo que já foi falado.

O excerto do Exemplo 4 parece confuso. Talvez revele alguma dificuldade de expressâo da participante. Ao mesmo tempo em que o conhecimento científico é concebido como "só uma cópia do que já fizeram", é enunciado que a produçăo do conhecimento parte de saberes especializados existentes ("pegar aquilo que já existe e aí colocar minhas ideias"). A necessidade da comprovaçăo das asserçóes no trabalho científico parece ser utilizada equivocadamente para sustentar a ideia da cópia ("é só uma cópia do que já fizeram"; "eu tenho que comprovar aquilo que eu estou falando"). A dificuldade de estabelecer diálogo com estudos realizados, conforme demandado para a escrita acadêmica, pode provocar o silenciamento das próprias vozes discentes. 0 excerto focalizado sinaliza a fragilidade da educaçăo científica usufruída.

Năo podemos ignorar a possibilidade de o enunciado exemplificado reproduzir o discurso reconhecido entre universitários: eles náo possuem autoridade para sustentar opiniôes nos próprios escritos acadêmicos. Sobre o assunto Demo, $(2015 ; 1996)$ afirma que a reproduçăo de conhecimento é uma deficiência do nosso sistema educacional como um todo, até mesmo os professores, por diferentes razóes, abrem máo da autoria da própria aula nos diferentes níveis de instruçăo formal, ficando reféns de livros didáticos na educaçāo básica ou de textos teóricos produzidos por outrem e utilizados como apostilas de aulas na universidade.

Conforme o discurso dominante reproduzido no Exemplo 4, a ciência é compreendida como produto de sujeitos e instituiçōes privilegiados. Apenas os detentores de altos níveis de escolarizaçâo ou usufruidores de saberes legitimados por produçóes textuais (dentre essas, livros, dissertaçôes e teses) podem ser considerados autores e detentores de conhecimentos. Essa compreensăo opóe-se às teses progressistas e empoderadoras defendidas por estudiosos como Demo (2015; 2010; 1996), Freire (2001) e Santos (2010).

No excerto do Exemplo 5 ilustramos, a compreensăo de ciência como desencadeadora de estudo ou investigaçâo. 


\section{Exemplo 5: Participante L1}

Resposta para questăo 01

[...] Ciência, para mim, é o estudo da natureza. [...] 0 que é fazer ciência eu năo sei exatamente. Mas o que é a ciência, eu acho que é o estudo da natureza. O estudo dos fenômenos que acontecem.

Ao longo da entrevista, a participante demonstrou bastante dificuldade para expressar a própria compreensăo de ciência. Isso ficou evidente nâo só no conteúdo verbal produzido, mas na fisionomia, gestos e hesitaçóes. Ao mesmo tempo em que é afirmado por duas vezes que ciência "é o estudo da natureza", também expressa a impossibilidade de compartilhar com alguma precisăo o que compreende por "fazer ciência" ("O que é fazer ciência eu nâo sei exatamente”).

Essa dificuldade observada também pode ser justificada pela limitada compreensâo de ciência compartilhada. Para L1, o estudo científico parece restrito às ciências da natureza, o que é corroborado pela incapacidade da participante em expressar alguma contribuiçăo científica produzida na própria área de formaçăo, que é a Licenciatura em Letras. Ao final da entrevista, ao ser questionada, L1 afirma explicitamente que desconhece alguma contribuiçấo da referida área para a sociedade e cita como exemplo de contribuiçăo científica as previsôes meteorológicas capazes de evitar desastres naturais.

Essa percepçâo restrita do domínio científico também foi compartilhada por outros entrevistados. Ainda que o enfoque investigativo deste artigo náo abranja a particularizaçăo das diferentes licenciaturas, podemos afirmar que esses resultados mostram especialmente uma fragilidade da educaçâo científica nas licenciaturas inseridas na grande área de conhecimento das humanidades. Insistimos em afirmar que esse fato ainda reflete alguns resquícios do modelo paradigmático dominante de ciência que, conforme explana Boaventura Santos (2008, p. 21), caracteriza "duas formas de conhecimento náo cientifico (e, portanto, irracional) potencialmente perturbadoras e intrusas: o senso comum e as chamadas humanidades ou estudos humanísticos (em que se incluíram, entre outros, os estudos históricos, filológicos, jurídicos, literários, filosóficos e teológicos)".

No excerto do Exemplo 6, ilustramos a autonomia e criticidade reveladas pelos acadêmicos das licenciaturas do agrupamento das ciências naturais, os quais nâo só explicaram espontaneamente e com segurança, mas exemplificaram a prática científica característica do próprio curso de formaçáo. Salientamos que, quando questionados diretamente sobre as ciências humanas, esses mesmos acadêmicos conseguiram exemplificar e expor a relevância das pesquisas nessa grande área de conhecimento.

\section{Exemplo 6: Participante Q}

\section{Resposta para questăo 02}

A partir do momento também que vamos no mercado popular de Araguaína, compramos, daqueles senhores, é produtos que eles mesmos fazem, mas eles nâo sabem explicar direito sobre "ah, qual é::: o que é que ele ocorre no organismo? Ele só::: é::: quais métodos é... você utilizou pra fazer esse produto tal tal tal?" Ele, às vezes, pode até o conhecimento dele pode ser que ele náo consiga explicar as etapas, consiga explicar o que é que acontece (naqueles) com aqueles produtos, mas ele sabe que tal coisa vai fazer bem pro organismo, tal coisa vai servir pra curar tal problema. Entâo quando a gente fala que a ciência (ela) pode entrar pra... pra... ajudar no dia a dia, que é que ela pode cooperar em coisas de hoje em dia, a gente tem que englobar diversas partes de... (como pode se dizer?) diversas partes estăo presentes ao nosso redor, desde o simples feirante ao médico na::: na::: na::: no hospital fazendo cirurgias entre outras coisas, utilizando a ciência ao seu favor.

Após sintetizar a história da Química, que, em seus primórdios, esteve atrelada à Alquimia, Q questiona a compreensâo legitimada de ciência e utiliza o contexto do 
comércio de remédios caseiros ou naturais de um mercado público local para ilustrar a produçâo de conhecimentos científicos por cidadâos comuns, os quais, certamente, nâo chegaram ao ensino superior. Em outras palavras, a questâo que se aponta por trás do excerto do Exemplo 6 é que o participante reconhece o conhecimento dito náo científico como legítimo ("a gente tem que englobar diversas partes de [...] diversas partes estăo presentes ao nosso redor, desde o simples feirante ao médico na::: na::: na::: no hospital fazendo cirurgias entre outras coisas, utilizando a ciência ao seu favor"), e afirma haver visóes preconceituosas quanto ao conhecimento popular, também denominado de senso comum ${ }^{14}$

No tocante ao segundo questionamento (Mencione algumas situaçôes na sociedade em que os conhecimentos produzidos pela ciência podem contribuir para solucionar ou aliviar problemas sociais), as respostas foram reunidas em dois agrupamentos: (1) exemplificaçăo na própria área de estudo do acadêmico; e (2) exemplificaçâo em área diferente da estudada pelo acadêmico. Houve ainda três ocorrências (EF1; H2 e P1) em que os participantes nâo compartilharam exemplificaçăo situada em alguma área específica do conhecimento, conforme excerto do Exemplo 7.

\section{Exemplo 7: Participante EF1}

\section{Resposta para questâo 02}

Eu acho que a parte, principalmente da pesquisa e da extensâo, que é de onde surge a pergunta, ou o questionamento, o que pode se melhorar na comunidade, a partir dos projetos de extensóes das universidades, daí que acontecem os grupos de estudos que acham uma soluçăo, que vai pra comunidade onde colhem as amostras daquele problema e juntamente em grupo encontram a soluçăo. Entăo eu acredito que os projetos de extensóes sáo grandes aliados nas resoluçōes desses problemas na comunidade.

Assim como explicitado por H1 (Exemplo 2), as atividades de pesquisa săo atreladas espontaneamente às de extensáo no Exemplo 7. Esses participantes parecem conceber contribuiçóes das pesquisas científicas quando atreladas a atividades de extensâo. Nâo temos precisăo ao analisar as falas de H1 e EF1 se a participaçăo ativa da comunidade externa à universidade está garantida nas supostas atividades de extensăo. A participaçâo passiva da comunidade externa, em funçâo da coleta ou geraçâo de material para pesquisa ou ainda no tocante à recepçăo dos benefícios produzidos na universidade, contradiz a abordagem do letramento científico assumido nesta pesquisa. Essa abordagem está alinhada ao conceito de comunicaçāo proposto por Freire (2001, p. 36), para quem os saberes săo construídos no diálogo, nas trocas de experiências, “o conhecimento se constitui nas relaçōes homem-mundo, relaçōes de transformaçăo, e se aperfeiçoa na problematizaçâo crítica destas relaçôes"15.

14 Segundo Boaventura Santos (2008, p. 88-89), "a ciência moderna construiu-se contra o senso comum que considerou superficial, ilusório e falso. A ciência pós-moderna procura reabilitar o senso comum por reconhecer nesta forma de conhecimento algumas virtualidades para enriquecer a nossa relaçáo com o mundo. É certo que o conhecimento do senso comum tende a ser um conhecimento mistificado e mistificador mas, apesar disso e apesar de ser conservador, tem uma dimensăo utópica e libertadora que pode ser ampliada através do dialogo com o conhecimento cientifico. Essa dimensẫo aflora em algumas das características do conhecimento do senso comum".

15 Freire (2001) contrapóe o conceito de comunicaçấo ao de extensâo. Segundo o autor, "no termo extensâo, está implícita a açáo de levar, de transferir, de entregar, de depositar algo em alguém, ressalta, nele, uma conotaçâo indiscutivelmente mecanicista" (FREIRE, 2001, p. 26). 
No Gráfico 3, apresentamos a análise quantitativa das categorias de exemplificaçâo das contribuiçóes das ciências na própria área de estudo do acadêmico participante ou em outras áreas.

Gráfico 3: Exemplificaçăo de contribuiçōes da ciência

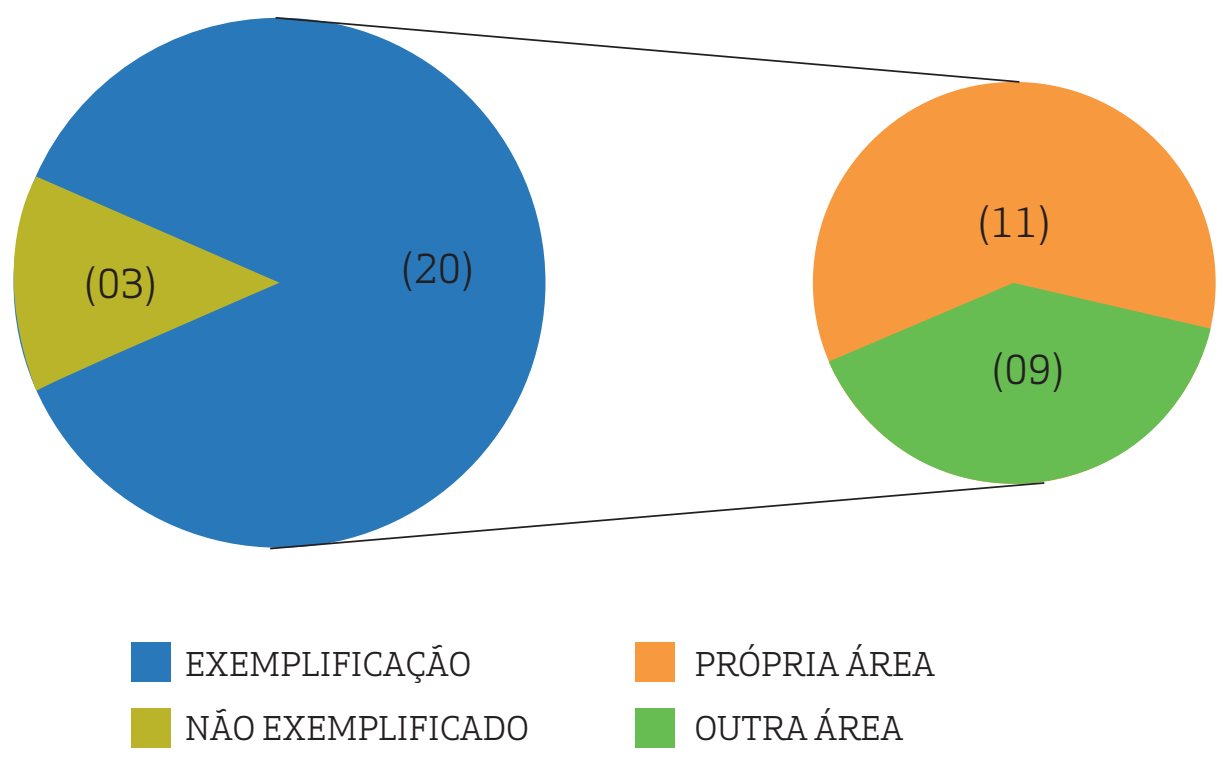

Fonte: autoria própria

Dos vinte e três participantes da pesquisa, vinte conseguiram exemplificar alguma contribuiçâo científica de qualquer área do conhecimento para a sociedade, enquanto três năo conseguiram exemplificar (EF1; H2 e P1). Onze participantes exemplificaram contribuiçôes da ciência na própria área de estudo, espontaneamente ou năo $(\mathrm{A} 1 ; \mathrm{B} 1$; B2; EF3; EF4; F1; F2; G1; G2; Q e M1). Nove participantes exemplificaram apenas em outras áreas diferentes dos próprios cursos (A2; EF1; FL1; FL2; H1; L1; L2; M2 e P2). Quatro participantes foram motivados pelos pesquisadores a compartilharem contribuiçôes originárias da própria área de licenciatura cursada (L1; L2; M1 e M2), mas apenas um explicitou as contribuiçōes demandadas (M1). Seis participantes só exemplificaram em outras áreas e năo foram questionados pelos pesquisadores sobre o próprio curso (A2; EF2; H1; FL1; FL2 e P2).

O aprofundamento da investigaçăo sobre a interferência da especializaçăo ou especificidade de cada licenciatura nos saberes científicos identificados pode ser encontrado em Silva et al (2018). A dimensăo alcançada por este artigo impossibilita o aprofundamento desta última questăo. 


\section{CONSIDERAÇÕES FINAIS}

Esta pesquisa foi motivada pela necessidade do desenvolvimento de uma educaçăo científica também direcionada a professores da escola básica, haja vista que as práticas de linguagem características do domínio científico precisam ser trabalhadas com maestria nas escolas, evitando-se a excessiva escolarizaçăo das atividades propostas, conforme mostrou, por exemplo, a pesquisa realizada por Silva, Tavares e Velez (2017). Nesse sentido, evitando a cobrança precipitada sobre os professores em serviço, realizamos um diagnóstico sobre as compreensôes de ciência compartilhadas por acadêmicos de diferentes licenciaturas, cursos superiores responsáveis pela formaçăo inicial de professores.

Os participantes compartilharam compreensôes simplificadas de ciência, seja por enfatizarem as pesquisas realizadas na grande área das ciências naturais, seja pelo conhecimento limitado ou náo explicitado das práticas científicas características do próprio curso em que estăo inseridos, a exemplo da Matemática ou, especialmente, na grande área das humanidades. Por um lado, os resultados nâo nos autorizam afirmar que as licenciaturas se configuraram como cursos marcados pela ausência da investigaçâo científica ou da produçấo do conhecimento. Houve participantes que demonstraram segurança ao responder as perguntas propostas. Por outro lado, os resultados mostraram que a história da ciência ainda pesa sobre os acadêmicos, pois foram recorrentes as falas reprodutoras de aspectos definidores do paradigma dominante de pesquisa, identificador da denominada ciência moderna.

Esta pesquisa mostrou a provável razăo das feiras científicas realizadas nas instituiçôes de ensino básico serem excessivamente escolarizadas ou nelas predominarem os trabalhos discentes vinculados, principalmente, às disciplinas de ciências naturais, mesmo que orientados por professores especialistas em disciplinas das humanidades, conforme apontou Fernandes (2016). É preciso desenvolver alguma política de visibilizaçâo do trabalho científico realizado na área de conhecimento das humanidades.

Destacamos a necessidade de maiores investimentos nas licenciaturas, especialmente no sentido de familiarizar os acadêmicos com práticas de investigaçāo científica, o que pode ocorrer a partir da ampliaçăo e fortalecimento de programas institucionais já existentes nas universidades, a exemplo do Programa de Iniciaçăo Científica (PIBIC) e Programa de Educaçáo Tutorial (PET) ou, até mesmo, do aprimoramento de atividades de pesquisa previstas nos currículos, a exemplo da produçấo dos Trabalhos de Conclusâo de Curso (TCC). Finalmente, lembramos que os formadores de professores precisam ser produtores de conhecimento, náo meros reprodutores de conteúdos elaborados por outras pessoas e que as atividades de ensino precisam se articular às de pesquisa.

\section{AGRADECIMENTOS}

O primeiro autor deste artigo agradece ao Conselho Nacional de Desenvolvimento Científico e Tecnológico (CNPq) pela bolsa de produtividade em pesquisa (PQ-2) concedida, contribuindo portanto para produçâo da pesquisa aqui apresentada (Processo 305094/2016-5). Este artigo apresenta resultados de investigaçóes produzidas no grupo de pesquisa Práticas de Linguagens - PLES (UFT/CNPq). 


\section{REFERÊNCIAS}

AKDUR, Tunç Erdal. Scientific Literacy: the Development of some Components of Scientific Literacy in Basic Education. Saarbrücken: VDM Verlag Dr. Müller, 2009.

BARTON, David; PAPEN, Uta. (Eds.). The Anthropology of Writing: Understanding Textually-Mediated Worlds. London: Continuum, 2010.

BRASIL. Base Nacional Comum Curricular: educaçâo é a base. (Versâo 20 de Dezembro) Brasília: MEC, 2017.

CELANI, Maria Antonieta Alba. Questōes de ética na pesquisa em Linguística Aplicada. Revista Linguagem \& Ensino. Pelotas: UCPel, v. 8, n. 1, p. 101-122, 2005.

CHASSOT, Attico. Alfabetizaçâo científica: questôes e desafios para a educaçâo. 7. ed. Ijuí: Editora UNIJUÍ, 2014.

CHASSOT, Attico. A ciência através dos tempos. 2. ed. Săo Paulo: Editora Moderna, 2004. CHASSOT, Attico. Alfabetizaçấo científica: uma possibilidade para a inclusâo social. Revista Brasileira de Educaçâo. Rio de Janeiro: ANPED, v. 8, n. 22, p. 89-100, 2003.

CUNHA, Rodrigo Bastos. Alfabetizaçăo Científica ou letramento científico?: interesses envolvidos nas interpretaçōes da noçăo de scientific literacy. Revista Brasileira de Educaçâo. Rio de Janeiro: ANPED, v. 22 n. 68, p. 169-186, 2017.

DEMO, Pedro. Aprender como autor. Săo Paulo: Editora Atlas, 2015.

DEMO, Pedro. Educaçâo e alfabetizaçâo científica. Campinas: Papirus, 2010.

DEMO, Pedro. Pesquisa: princípio científico e educativo. 14. ed. Săo Paulo: Cortez Editora, 1996.

FERNANDES, Elizangela Rocha. Letramento científico no ensino básico público no município de Palmas - Tocantins. 2016. 106f. Dissertaçăo (Mestrado em Letras: Ensino de Língua e Literatura) - Universidade Federal do Tocantins, Câmpus de Araguaína, 2016.

FLICK, Uwe. Uma introduçâo à pesquisa qualitativa. Traduçăo Sandra Netz. 2. ed. Porto Alegre: Bookman, 2004.

FREIRE, Paulo. Extensăo ou comunicaçáo?. Traduçăo Rosisca Darcy de Oliveira. 11. ed. Rio de Janeiro: Paz e Terra, 2001.

KLEIMAN, Angela (Org.). Os significados do letramento: uma nova perspectiva sobre a prática social da escrita. Campinas: Mercado de Letras, 1995.

KUHN, Thomas S. A Estrutura das Revoluçōes Científicas. Traduçăo Beatriz V. Boeira e Nelson Boeira. 9. ed. Săo Paulo: Editora Perspectiva, 2009[1962].

MARINHO, Marildes.; CARVALHO, Gilcinei Teodoro. (Orgs.). Cultura escrita e letramento. Belo Horizonte: Editora UFMG, 2010.

MAY, Tim. Pesquisa Social: questōes, métodos e processos. Traduçāo Carlos Alberto Silveira Netto Soares. 3. ed. Porto Alegre: Artmed. 2004. 
PENNYCOOK, Alastair. Critical Applied Linguistics: a Critical Introduction. London: Routledge, 2001.

SANTOS, Boaventura Sousa. Para além do pensamento abissal: das linhas globais a uma ecologia de saberes. In: SANTOS, Boaventura de Sousa; MENESES, Maria P. (Orgs.). Epistemologia do sul. Sáo Paulo: Cortez Editora, 2010, p. 31-83.

SANTOS, Boaventura Sousa. Um discurso sobre as ciências. 5. ed. Săo Paulo: Cortez, 2008.

SANTOS, Wildson Luiz Pereira. Educaçâo científica na perspectiva de letramento como prática social: funçôes, princípios e desafios. Revista Brasileira de Educaçăo, v. 12, n. 36, p. 474-550, 2007.

SILVA, Wagner Rodrigues. Letramento científico na formaçăo inicial do professor. Práticas de Linguagem. Juiz de Fora: UFJF, v. 6, p. 8-23, 2016. Número especial.

SILVA, Wagner Rodrigues. CODEIRO, Mayron R.; FARAH, Bárbara F.; MORAES, Carlos W. R.; SOUSA, Dijan L.; SILVA, Leide L. S.; MENDES, Victor C. B. B. Ciências nas licenciaturas? Linguagem: Estudos e Pesquisa. Catalăo: UFCAT, v. 22, n. 1, p. 83-108, 2018.

SILVA, Wagner Rodrigues. GUIMARÅES, Elton Vieira; MEDEIROS, Ivanildo Alves. Construçâo de objetos de conhecimento para aulas de língua portuguesa na abordagem do letramento científico. Revista Brasileira de Linguística Aplicada. Belo Horizonte: UFMG, 2018.

SILVA, Wagner Rodrigues. TAVARES, Elcia; VELEZ, Luciana de Carvalho Barbalho. Trabalho pedagógico com escrita em aula de história: o que dizem as diretrizes oficiais? Trabalhos em Linguística Aplicada. Campinas: Unicamp, v. 56, n.3, p. 885-911, 2017.

SOARES, Magda. Letramento e escolarizaçăo. In: RIBEIRO, Vera Masagăo. (Org.). Letramento no Brasil. Sáo Paulo: Global Editora, 2003, p. 89-113.

Recebido em janeiro de 2018.

Aceite em março de 2018. 